\title{
JCEIB
}

Journal Chemical Engineering and Industrial Biotechnology (JCEIB)

ISSN: 0126-8139 (Online); Open Access

Volume 5Issue 5 pp. 48-56; May 2019

(C)Universiti Malaysia Pahang Publisher

DOI: https://doi.org/10.15282/JCEIB-V5-05.29/3/2019/5.5

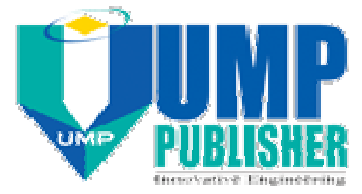

\section{KINETIC STUDY OF PALM OIL MILL EFFLUENT (POME) TREATMENT BY ACTIVATED SLUDGE}

\author{
W.L.Wun, G.K.Chua*, S.Y.Chin, N.Zainol \\ Faculty of Chemical \& Natural Resources Engineering, Universiti Malaysia Pahang, 26300 Gambang, \\ Pahang, Malaysia \\ *Corresponding author: chua@ump.edu.my \\ Tel: 09-5492828, Fax: 09-549 2399
}

\begin{abstract}
Kinetic parameter is a basis for design and optimization of activated sludge POME treatment. In fact, most of the kinetic parameter value used in design and optimization are default values taken from municipal wastewater. The kinetic parameters for POME treatment have not been thoroughlystudied and most of the system is using the Activated Sludge Models (ASM), either in modelling or design. Thus, the kinetic study of POME treatment by activated sludge system were carried out to obtain the kinetic parameters for the POME treatment plant design calculation.In this study, POME treatment was carriedout in batch studiesinto $14 \mathrm{~L}$ aeration tank with activated sludge for the biological oxidation process with optimum pH at $6.5 \pm 0.1$, MLVSS of $2000 \pm$ $200 \mathrm{mg} / \mathrm{Lfor} \mathrm{HRT}$ of $48 \mathrm{~h}$ and feeding with $650 \pm 20 \mathrm{mg} \mathrm{BOD} / / \mathrm{L}$ of anaerobic treated POME, while SRT was controlled at a range of 10 days to 20 days with interval of 2 days for the kinetic study experiment. From this kinetic study, the kinetic parameters for COD and BOD basis had been determined for maximum yields coefficient $(Y)$, endogenous decay coefficient $\left(k_{d}\right)$, maximum specific substrate utilization rate $(k)$ and half-velocity constant $\left(K_{s}\right)$ at $0.2369 \mathrm{mg}$ VSS $/ \mathrm{mg}$ COD, 0.1060 day $^{-1}, 2.2717$ day $^{-1}$ and $758.7705 \mathrm{mg} / \mathrm{L}$ for COD basis whilst the kinetic parameters value for BOD basis were $0.6718 \mathrm{mg} \mathrm{VSS} / \mathrm{mg} \mathrm{BOD}_{3}, 0.0658 \mathrm{day}^{-1}, 1.4136$ day $^{-1}$ and $556.1526 \mathrm{mg} / \mathrm{L}$, respectively. Since the BOD is one of the discharge parameters in discharge regulatory, thus kinetic parameters for BOD basis will be used for the system design of POME treatment.
\end{abstract}

Keywords: Kinetic study; Kinetic parameter; Palm oil mill effluent; Activated sludge

\subsection{INTRODUCTION}

Palm oil industry is one of the very important agriculturally based industries in Malaysia for the past decades. According to the statistic of Malaysian Palm Oil Board (MPOB) in year 2017 (MPOB, 2017), total 454 of palm oil mills in Malaysia have produced about 112.19 million tonne of Fresh Fruit Bunch (FFB). Yacob et al. (2005) estimated that approximately 0.50 - 0.75 tonnes of Palm Oil Mill Effluent (POME) will be discharged for every tonne of FFB from mill. Thus, total POME discharged to the river in year 2016 was estimated in the range of $56.10-84.14$ million tonnes. The raw POME which is generated by palm oil mill is hot, acidic ( $\mathrm{pH}$ between 4.0 to 5.0 ) and brownish colloidal suspension containing high concentration of organic matter, i.e. 
COD (50,000 mg/L), BOD (25,000 mg/L), total solids (40,500 mg/L) and oil \& grease $(4,000 \mathrm{mg} / \mathrm{L})$ (Alhaji, 2016). When the untreated POME discharged into the water bodies, it may have a deleterious environmental impact especially to the aquatic life (Azmi \& Yunos, 2014).

In order to comply with the DOE discharge standard, other technologies or systems had been used in conjunction with the conventional ponding treatment system, especially the activated sludge system that is considered as low operating cost, simple and ease of handling (Wong, 1980; Ma \& Ong, 1984). However, the discharged POME has yet to meet with the regulatory discharge limit consistently. In practical, the activated sludge system is designed and calculated based on the organic loading concentration, namely $\mathrm{BOD}_{3}$ and COD from the raw POME by referring to the DOE design guidance book (DOE, 2010a), which is typically based on the empirical design criteria that adopted from sewage wastewater.

In the past, the biological wastewater treatments plant was designed based on the empirical parameters which developed by observation and experience such as aeration detention time, hydraulic retention time and organic loading rate. However, over the last decades, the design of biological wastewater treatment plant was based on biological kinetic equations which have been developed according to the concepts of microbial growth kinetics to determine the kinetics coefficient such as maximum yield coefficient $(\mathrm{Y})$ and endogenous decay coefficient $\left(k_{d}\right)$, maximum specific substrate utilization rate $(k)$ and half-velocity constant $\left(\mathrm{K}_{\mathrm{s}}\right)$.

According to Tchobanoglous \& Stensel (2004), value $Y$ and $K_{d}$ can be obtained from the equation from the biomass mass balance of the activated sludge process that is shown in Eq. (1).

$$
\frac{1}{\theta_{c}}=Y \frac{Q_{i}\left(S_{i}-S_{e}\right)}{X V_{r}}-k_{d}
$$

where $\theta_{c} \quad=$ Solid retention time (day)

$Y \quad=$ Yield coefficient (mg VSS/mg BOD)

$Q_{i} \quad=$ Flow of influent (L/day)

$S_{i} \quad=$ Influent concentration $(\mathrm{mg} \mathrm{BOD} / \mathrm{L})$

$S_{e} \quad=$ Effluent concentration $(\mathrm{mg} \mathrm{BOD} / \mathrm{L})$

$X \quad=$ Mixed liquor volatile suspended solid (MLVSS) in aeration tank

(mg VSS/L)

$V_{r} \quad=$ Aeration Tank volume (L)

$k_{d} \quad=$ Endogenous decay coefficient $\left(\right.$ day $\left.^{-1}\right)$ 
While value $k$ and $K_{s}$ can be determined from the specific substrate utilization rate, $U$ as shown in Eq. (2).

$U=\frac{k S_{e}}{\left(K_{s}-S_{e}\right)}$

where $k=$ Specific substrate utilization rate $\left(\right.$ day $\left.^{-1}\right)$

$S_{e} \quad=$ Effluent concentration $(\mathrm{mg} \mathrm{BOD} / \mathrm{L})$

$K_{s} \quad=$ Half-velocity constant (mg/L of BOD)

As mentioned in DOE guidance document, for conventional aeration activated sludge system design, default value for yield coefficient $(Y)$ and decay coefficient $\left(k_{d}\right)$ are $0.4-$ $0.8 \mathrm{~kg} \mathrm{VSS} / \mathrm{kg} \mathrm{BOD}_{5}$ and $0.03-0.15$ day $^{-1}$ respectively. Meanwhile, default value for yield coefficient $(Y)$ and decay coefficient $\left(k_{d}\right)$ are $0.1-0.3 \mathrm{~kg} \mathrm{VSS} / \mathrm{kg} \mathrm{BOD}_{5}$ and 0.03 -0.15 day $^{-1}$ respectively for extended aeration activated sludge system design (DOE, 2010a).

In determination of kinetic parameters in the activated sludge process of domestic wastewater, Najafpour et al. (2007) had reported that the decay coefficient $\left(k_{d}\right)$, maximum specific substrate utilization rate $(k)$ and half-velocity constant $\left(K_{s}\right)$ were determined to be 0.06 day $^{-1}, 1.71$ day $^{-1}$ and $85.5 \mathrm{mg} / \mathrm{L}$, respectively with SRT of 8 days and a COD removal efficiency up to $90 \%$. However, there was no yield coefficient has been reported in this study. In other literatures of municipal wastewater study, the investigation had shown that the yield coefficient $(Y)$, decay coefficient $\left(k_{d}\right)$, maximum specific substrate utilization rate $(k)$ and half-velocity constant $\left(K_{s}\right)$ for conventional activated sludge process were in the range of $0.48-0.80 \mathrm{mg} \mathrm{VSS} / \mathrm{mg}$ sCOD, 0.01890.0260 day $^{-1}, 0.95-0.98 \mathrm{day}^{-1}$ and 52-71 mg sCOD/L, respectively, and for extended aeration activated sludge system, the yield coefficient $(Y)$, decay coefficient $\left(k_{d}\right)$, maximum specific substrate utilization rate $(k)$ and half-velocity constant $\left(K_{s}\right)$ for conventional activated sludge process were in the range of $0.6174-1.2512 \mathrm{mg} \mathrm{VSS} / \mathrm{mg}$ sCOD, 0.0198-0.0309 day ${ }^{-1}$, 1.96-3.17 $\mathrm{day}^{-1}$ and 311.7-508.0 mg sCOD/L, respectively (Mardani et al., 2011). Kinetic study of POME in Sequencing Batch Reactor (SBR) system by respirometry method also been reported for $Y, k_{d}$, and $K_{s}$ at value of $0.272 \mathrm{mg}$ VSS/mg COD, 0.131 day $^{-1}$ and $429 \mathrm{mg} / \mathrm{L}$ of COD, respectively (Lim \& Vadivelu, 2014).

\subsection{MATERIALS AND METHODS}

\subsection{POME Sample Preparation and Characteristic}

Anaerobic treated POME was collected from Anaerobic Pond 4 in Neram Palm Oil Mill, Kemaman, Terengganu. The sample was stored at $4^{\circ} \mathrm{C}$ until the experiment.

\subsection{Reactor Set Up}

Experiment forkinetic study of activated sludge in POME treatment was carried out in batch studies by transferring $5 \mathrm{~L}$ of acclimated activated sludge into $14 \mathrm{~L}$ aeration tank completed with air flow output of $110 \mathrm{~L} / \mathrm{min}$ and pressure at $2 \mathrm{MPa}$ aquarium air pump as shown in Figure 1. 


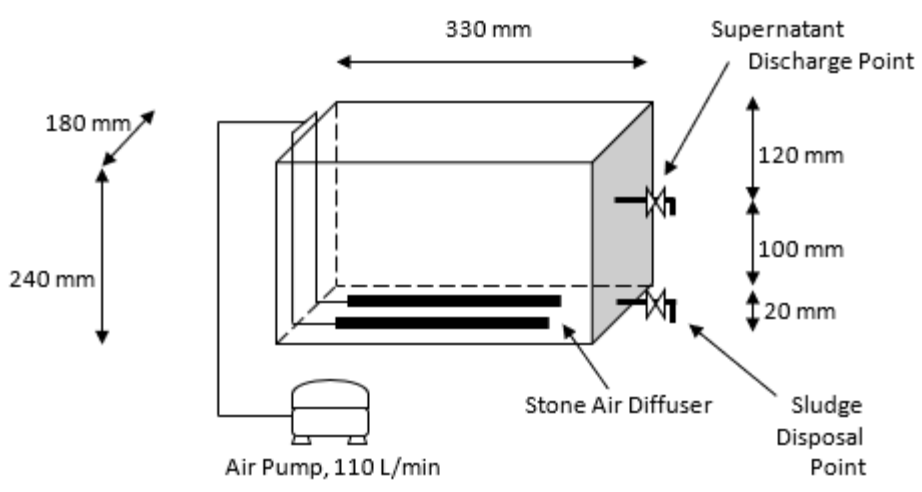

3.0

Figure 1: Line sketch of sequencing batch reactor

The experiment was carried out bases on the F/M ratio of $0.3 \mathrm{~kg}$ BOD/kg MLVSS.day with the optimum condition that gained from the previous studies, where optimum $\mathrm{pH}$ at $6.5 \pm 0.1$ with $2000 \pm 200 \mathrm{mg} / \mathrm{L}$ of MLVSS in the system for HRT of $48 \mathrm{~h}$ and feeding with $650 \pm 20 \mathrm{mg} \mathrm{BOD}_{3} / \mathrm{L}$ of POME (Wun et al., 2017). For this kinetic study, experiment was carried out in batch mode and all the experiments were run in quadruplicate where SRT was controlled at a range of 10 to 20 days with interval of 2 days by adjusting the volume of sludge wasting from the aeration tank according to the Eq. 3 below.

$\theta_{c}=\frac{V_{r} X}{\left(Q_{i}-Q_{w}\right) X_{e}+Q_{w} X_{w}}$

Where $Q_{w} \quad=$ Flow of wasted activated sludge (WAS) (L/day)

$\mathrm{X}_{\mathrm{e}} \quad=$ TSS of effluent $(\mathrm{mg} / \mathrm{L})$

$\mathrm{X}_{\mathrm{w}} \quad=$ TSS of wasted activated sludge $(\mathrm{mg} / \mathrm{L})$

Since the $X_{w}>>X_{e}$, thus,

$\theta_{c}=\frac{V_{r} X}{Q_{w} X_{w}}$

So, the flowrate of wasted activated sludge (L/day) that need to be removed from the aeration tank for the different solid retention time is:

$\theta_{w}=\frac{V_{r} X}{Q_{c} X_{w}}$

For the $Y$ and $K_{d}$ determination, by linearizing the Eq.1: 
$\frac{1}{\theta_{c}}=Y U-k_{d}$

Where $U=\frac{S_{i}-S_{e}}{\theta X}$

A plot of reciprocal of solids retention time, $1 / \theta_{c}\left(\right.$ day $\left.^{-1}\right)$ versus specific substrate utilization rate, $U\left(\right.$ day $\left.^{-1}\right)$ can be constructed using the data obtained from the above experiment to get the maximum yields coefficient $(Y)$ and endogenous decay coefficient $\left(k_{d}\right)$ from the gradient and the $y$-intercept of the plot, respectively. Similar with above methods, by linearizing Eq. 2, maximum specific substrate utilization rate $(k)$ and halfvelocity constant (Ks) can be obtained as following equation (Eq. 8):

$\frac{1}{U}=\frac{K_{s}}{k S_{e}}+\frac{1}{k}$

A plot of reciprocal of specific substrate utilization rate, $1 / U$ (day) versus reciprocal effluent $\mathrm{BOD}_{3}, 1 / S_{e}(\mathrm{~L} / \mathrm{mg})$ can be constructed using the data obtained from above similar experiment and determined the maximum specific substrate utilization rate $(k)$ and half-velocity constant $(K s)$ value from the gradient and the $y$-intercept of the plot, respectively.

\subsection{Analytical Methods}

All analytical determination of $\mathrm{BOD}_{3}$, COD, TSS and MLVSS were carried out in accordance with the Standard Methods for the Examination of Water and Wastewater (APHA, 1989). According to the EQA 1974, $\mathrm{BOD}_{3}$ for POME sample were analysed for 3 days incubation at $30^{\circ} \mathrm{C}$. COD was measured according to Reactor Digestion Method (Method 8000) at a wavelengthof $620 \mathrm{~nm}$ (APHA 5220 D) by using DRB 200 Reactor and measured by DR 890 Spectrophotometer. TSS were measured as outlined in Standard Methods APHA 2540 D (total suspended solids dried at $103-105^{\circ} \mathrm{C}$ ) while MLVSS were measured as outlined in Standard Methods APHA 2540 E (volatile solids ignited at $550^{\circ} \mathrm{C}$ ). $\mathrm{pH}$ was measured by using $\mathrm{pH}$ meter (Seven Easy, Mettler Toledo, USA) and was conducted according to Standard Methods APHA 4500- $\mathrm{H}^{+}$B.

\subsection{RESULTS AND DISCUSSION}

For the kinetic analysis experiment, the batch study was conducted where performance data were measured and recorded. The performance data including $\mathrm{BOD}_{3}$ concentration of POME influent and effluent, COD concentration of POME influent and effluent, mixed liquor volatile suspended solids, flow rate of influent and wasted activated sludge as well as volatile suspended solids concentration of wasted activated sludge as shown in Table 1.The MLVSS concentration in aeration tank was found increase gradually from $2,190 \mathrm{mg} / \mathrm{L}$ to $3,756 \mathrm{mg} / \mathrm{L}$ for solid retention time $\left(\theta_{c}\right)$ of activated sludge from 10 to 20 days, by converting the POME organic matter into the biomass via biodegradation process. Nevertheless, the reduction of $\mathrm{BOD}_{3}$ and COD was found not significant, which might due to the present of non-readily biodegradable matter in POME that not easily biodegraded by microorganism (Rasdy et al., 2008) 
Table 1:Performance data for the batch study in POME treatment by activated sludge

\begin{tabular}{|c|c|c|c|c|c|c|c|}
\hline $\begin{array}{c}\theta_{c} \\
\text { (day } \\
\text { ) }\end{array}$ & $\begin{array}{c}\text { Influent } \\
\text { BOD, } \\
S_{i b}(\mathrm{mg} / \mathrm{L} \\
)\end{array}$ & $\begin{array}{c}\text { Influent } \\
\text { COD, } \\
S_{i c}(\mathrm{mg} / \mathrm{L} \\
)\end{array}$ & $\begin{array}{c}\text { MLVSS } \\
, X \\
(\mathrm{mg} / \mathrm{L})\end{array}$ & $\begin{array}{c}\text { TSS } \\
\text { WAS, } \\
X_{w}(\mathrm{mg} / \mathrm{L} \\
)\end{array}$ & $\begin{array}{c}\text { Flow } \\
\text { WAS, } \\
Q_{w} \\
\text { (L/day } \\
\text { ) } \\
\end{array}$ & $\begin{array}{c}\text { Effluent } \\
\text { BOD, } \\
S_{e b}(\mathrm{mg} / \mathrm{L} \\
)\end{array}$ & $\begin{array}{c}\text { Effluent } \\
\text { COD, } \\
S_{e c}(\mathrm{mg} / \mathrm{L} \\
)\end{array}$ \\
\hline 10 & 684 & 2,464 & 2,190 & 2,933 & 0.34 & 122 & 458 \\
\hline 12 & 659 & 2,388 & 2,588 & 3,188 & 0.28 & 98 & 412 \\
\hline 14 & 668 & 2,468 & 2,750 & 3,776 & 0.25 & 94 & 386 \\
\hline 16 & 659 & 2,483 & 3,214 & 4,426 & 0.22 & 86 & 342 \\
\hline 18 & 667 & 2,588 & 3,467 & 5,567 & 0.19 & 83 & 326 \\
\hline 20 & 644 & 2,456 & 3,756 & 5,687 & 0.18 & 78 & 310 \\
\hline
\end{tabular}

From the plot as shown in Figures2 and 3, kinetic parameters of POME treatment by activated sludge process for maximum yields coefficient $(Y)$, endogenous decay coefficient $\left(k_{d}\right)$, maximum specific substrate utilization rate $(k)$ and half-velocity constant $\left(K_{s}\right)$ for $\mathrm{BOD}_{3}$ and COD were determined and summarized in Table 2.

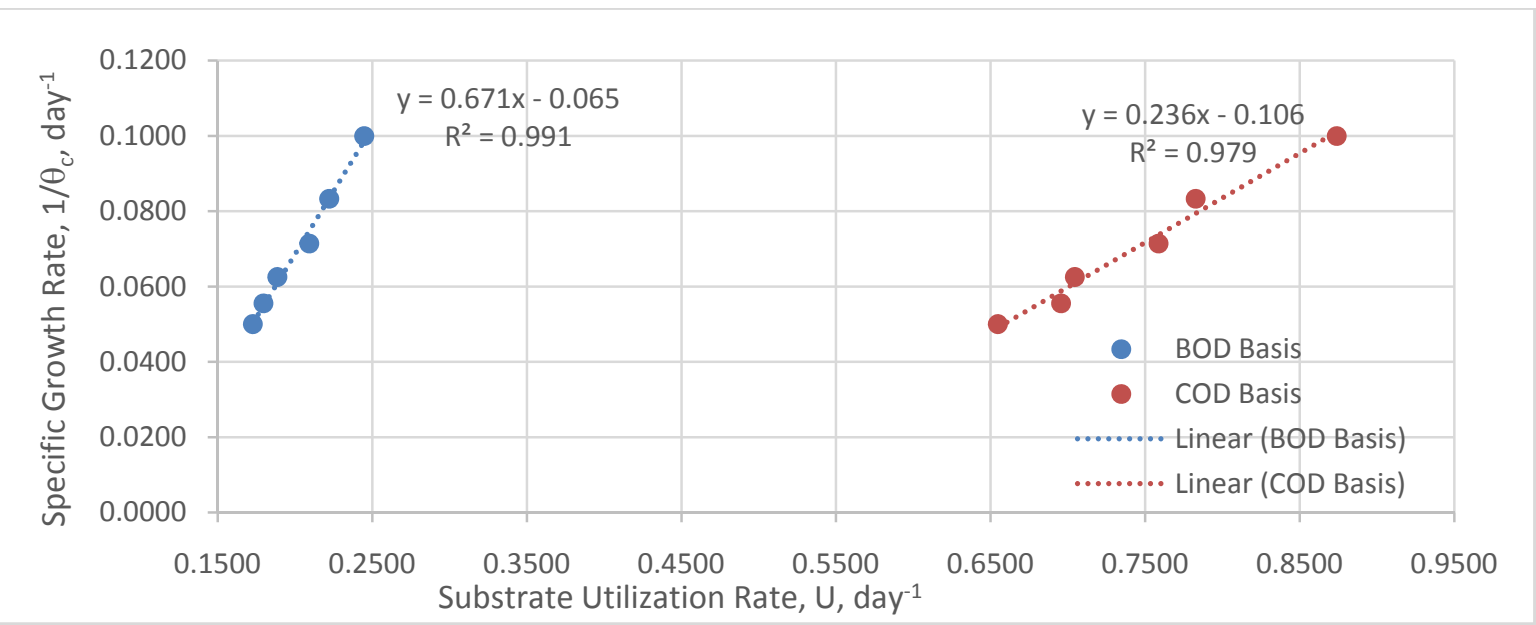

Figure 2: Plot of specific growth rate versus substrate utilization rate for maximum yields coefficient $(Y)$ and endogenous decay coefficient $\left(k_{d}\right)$ determination by using $\mathrm{BOD}_{3}$ and COD result 


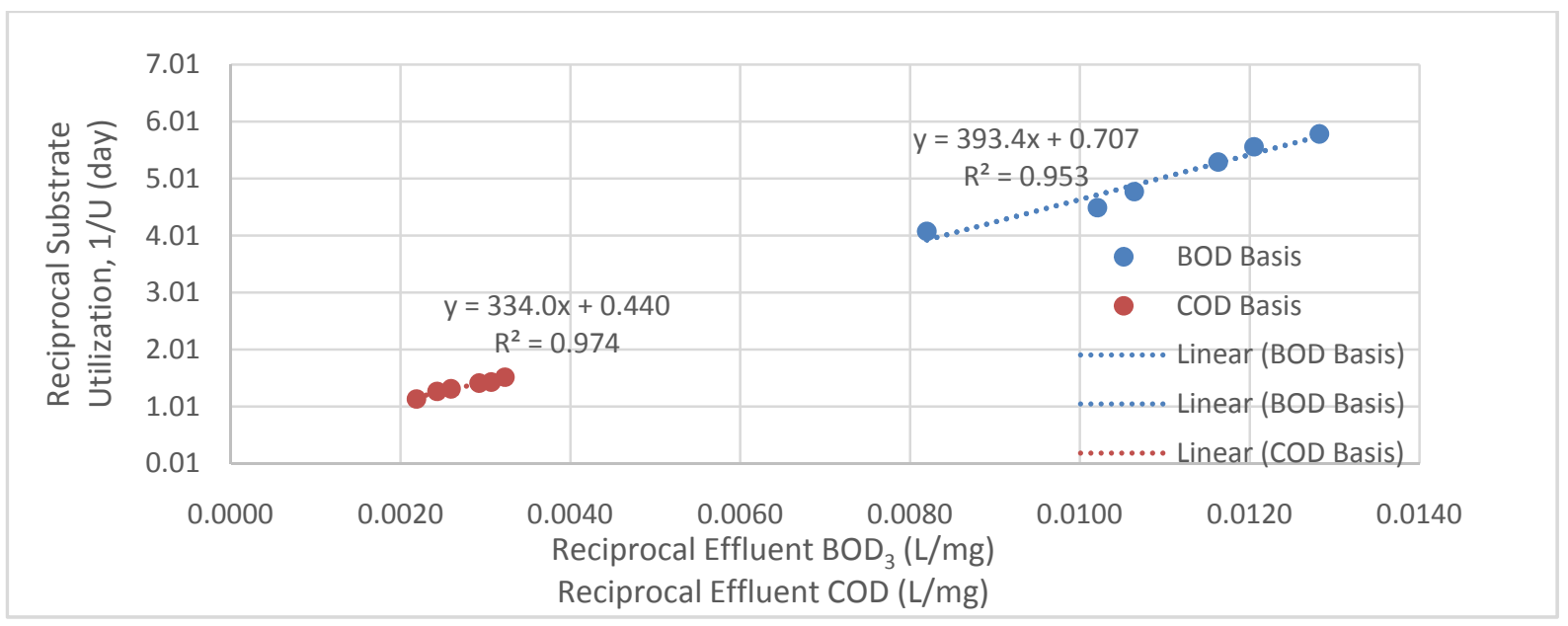

Figure 3: Plot of reciprocal substrate utilization versus reciprocal effluent for maximum specific substrate utilization rate $(k)$ and half-velocity constant $\left(K_{s}\right)$ determination by using $\mathrm{BOD}_{3}$ and $\mathrm{COD}$ result

Table 2: Kinetic parameters for the POME treatment by activated sludge process

\begin{tabular}{cccc}
\hline POME concentration & Kinetic Parameters & Unit & Value \\
\hline $\mathrm{BOD}_{3}$ & $Y$ & $\mathrm{mg} \mathrm{VSS} / \mathrm{mg} \mathrm{BOD}_{3}$ & 0.6718 \\
& $K_{d}$ & day $^{-1}$ & 0.0658 \\
& $K_{s}$ & $\mathrm{mg} / \mathrm{L} \mathrm{of} \mathrm{BOD}_{3}$ & 556.1526 \\
& $k$ & day $^{-1}$ & 1.4136 \\
& & & \\
$\mathrm{COD}$ & $Y$ & $\mathrm{mg} \mathrm{VSS} / \mathrm{mg} \mathrm{COD}^{-1}$ & 0.2369 \\
& $K_{d}$ & day $^{-1}$ & 0.1060 \\
& $K_{s}$ & mg/L of COD & 758.7705 \\
& $k$ & day $^{-1}$ & 2.2717 \\
\hline
\end{tabular}

Determination of kinetic parameters is essential for the aeration activated sludge system design especially the yields coefficient $(Y)$ and endogenous decay coefficient $\left(k_{d}\right)$. According to DOE (2010a), the recommended of design criteria for extended aeration activated sludge system of $Y$ and $K_{d}$ are $0.1-0.3 \mathrm{~kg} \mathrm{VSS} / \mathrm{kg} \mathrm{BOD}_{3}$ and $0.03-0.15$ day $^{-}$ ${ }^{1}$. However, in this study, the kinetic parameters of $Y$ and $K_{d}$ were found at $0.6718 \mathrm{~kg}$ $\mathrm{VSS} / \mathrm{kg} \mathrm{BOD}{ }_{3}$ and 0.0658 day $^{-1}$. The value obtained for $K_{d}$ was found within the DOE recommendation value, but the value gained for $Y$ was bigger than the DOE recommendation value. This indicated that the design of the aeration activated sludge system for POME treatment is under capacity if compare to the design value recommended by DOE. In fact, the volume of aeration activated sludge system has direct correlation with the value $Y$ as following equation (Tchobanoglous \& Stensel 2004; Davis, 2010; Shun, 2014):

Aeration Tan $k$ Volume, $V_{r}=\frac{Q_{c} Q Y\left(S_{i}-S_{e}\right)}{X\left[1+k_{d}-\theta_{c}\right]}$

Where $\theta_{c} \quad=$ Solid Retention Time (day)

$Q \quad=$ Influent flow rate $\left(\mathrm{m}^{3} /\right.$ day) 


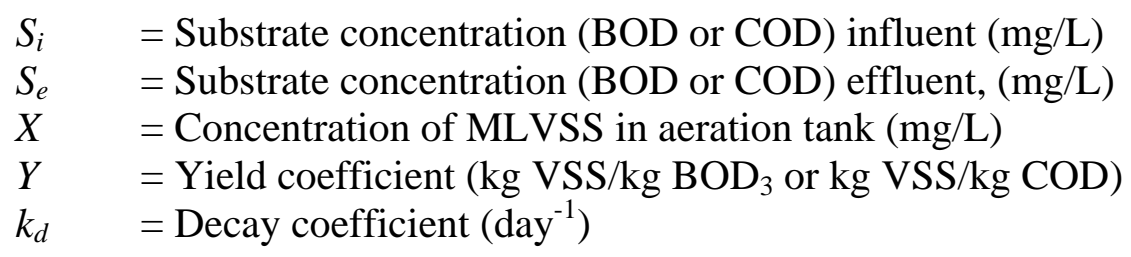

For the palm oil mill production capacity of 45 ton/h for $24 \mathrm{~h}$ operation time per day with POME discharge ratio at $0.65 \mathrm{~m}^{3} /$ ton of $\mathrm{FFB}$, volume of aeration tank was calculated at $916.53 \mathrm{~m}^{3}$ and $1,017.12 \mathrm{~m}^{3}$ by using DOE default value and value from this study, respectively. It is clearly shown that the design from DOE recommendation is about $100 \mathrm{~m}^{3}$ or $10 \%$ smaller than the design from this study. This might be one of the reasons that most of the POME treatment system doesn't meet the DOE final discharge standard consistently.

Meanwhile, the value of $K_{s}$ and $k$ was found at $556.1526 \mathrm{mg} / \mathrm{L}$ of $\mathrm{BOD}_{3}$ and 1.4136 day ${ }^{-}$ 1 , respectively, but in practical, value of $K_{s}$ and $k$ never used for system design calculation and there was no study has been reported for the above kinetics parameters in BOD basis. However, the same kinetic study of POME in SBR system based on COD basis had reported the $Y$ and $k_{d}$ at a value of $0.272 \mathrm{mg} \mathrm{VSS} / \mathrm{mg}$ COD and 0.131 day $^{-1}$, respectively (Lim and Vadivelu, 2014). The $Y$ and $K_{d}$ value are higher than the value that was obtained in this study, where $Y$ and $K_{d}$ was found at a value of $0.2369 \mathrm{mg}$ VSS/mg COD, 0.1060 day $^{-1}$ respectively. On the other hand, the reported $K_{s}$ value was $429 \mathrm{mg} / \mathrm{L}$ (Lim and Vadivelu, 2014), which is lower than the value of $758.7705 \mathrm{mg} / \mathrm{L}$ that gained from this study. The differences of the $Y, K_{d}$ and $K_{s}$ value might due to the growing condition and microbial species involve in the biological process. Thus, more thorough study needs to be done to get more precise values of growth kinetic in POME treatment.

\subsection{CONCLUSIONS}

The success of the biological treatment processdepends on the treatment system design. Hence, to get the kinetic parameters that will be used for the aeration tank design, a kinetic study has been carried out by using POME as substrate and activated sludge as inoculum. From the kinetic study experiment, the kinetic parameters for COD and BOD basis had been determined for maximum yields coefficient $(Y)$, endogenous decay coefficient $\left(k_{d}\right)$, maximum specific substrate utilization rate $(k)$ and half-velocity constant $\left(K_{s}\right)$ at $0.2369 \mathrm{mg}$ VSS/mg COD, 0.1060 day $^{-1}$, 2.2717 day $^{-1}$ and 758.7705 $\mathrm{mg} / \mathrm{L}$ for COD basis whilst the kinetic parameters value for BOD basis were $0.6718 \mathrm{mg}$ $\mathrm{VSS} / \mathrm{mg} \mathrm{BOD}_{3}, 0.0658$ day $^{-1}, 1.4136$ day $^{-1}$ and $556.1526 \mathrm{mg} / \mathrm{L}$, respectively. However, due to the environmental regulatory for BOD discharge standard, kinetic parameters for BOD basis is more appropriate for the calculation of POME treatment system design.

\section{REFERENCES}

Alhaji, A.M., Sanaullah, K., Lim, S.F., Khan, A., Hipolito, C.N., Abdullah, M.O., Bhawani, S.A. and Jamil, T. 2016. Photocatalytic treatment technology for palm oil mill effluent (POME) - A review. Process Safety and Environmental Protection. 102, 673-686.

APHA, 1989. Standard Methods for the Examination of Water and Wastewater, $20^{\text {th }}$ ed. Washington D.C, USA: American Public Health Association. 
Azmi, N.S. and Yunos, K.F.M 2014. Wastewater treatment of palm oil mill effluent (POME) by ultrafiltration membrane separation technique coupled with adsorption treatment as pre-treatment. Agriculture and Agricultural Science Procedia. 2, 257-264.

Davis, M.L. 2010. Water and Wastewater Engineering - Design Principles and Practice (Professional Edition)(pp. 23-1 - 23-19). McGraw-Hill, USA.

Department of Environment Malaysia (DOE), 2010. Guidance Document on the Design and Operation of Industrial Effluent Treatment Systems, Specified in Regulation 5, Environmental Quality (Industrial Effluent) Regulation 2009. $2^{\text {nd }}$ Edition. Department of Environment Malaysia.

Lim, J.X. and Vadivelu, V.M. 2014. Treatment of agro based industrial wastewater in sequencing batch reactor: performance evaluation and growth kinetics of aerobic biomass. Journal of Environmental Management. 146, 271-225.

Ma, A.N. and Ong, A.S.H. 1985. Pollution Control in Palm Oil Mills in Malaysia. Palm Oil Research Institute of Malaysia (PORIM). Journal of the American Oil Chemist's Society (JAOCS).63(2), 261-266.

MPOB, Malaysia Palm Oil 2017. http://bepi.mpob.gov.my/index.php/en/statistics/sectoral-status/179-sectoralstatus-2017/803-number-a-capacities-of-palm-oil-sectors-2017.html.

Rasdy, N.F.A., Sanagi, M.M., Ibrahim, W.A.W. and Naim, A.A. 2008. Determination of polycyclic aromatic hydrocarbon in palm oil mill effluent by Soxhlet extraction and gas chromatography-flame ionization detection. The Malaysian Journal of Analytical Sciences. 12(1), 16-21.http://www.ukm.my/mjas/v12_n1/3.pdf

Shun D.L. 2014. Water and Wastewater Calculations Manual (pp. 639 - 657). The McGraw-Hills Education.

Tchobanoglous, G., Burton, F.L. and Stensel, H.D. 2004. Wastewater Engineering Treatment and Reuse (Fourth Edition) (pp. 588 - 591). Metcalf \& Eddy Inc., McGraw-Hills Education, New York, USA.

Wong, K.K..1980. Application of Ponding Systems in the Treatment of Palm Oil Mill and Rubber Mill Effluents. Pertanika. 3(2),133141.https://core.ac.uk/download/pdf/42989362.pdf

Wun, W.L., Chua, G.K. and Chin, S.Y. 2017. Effect of palm oil mill effluent (POME) treatment by activated sludge. Journal CleanWAS. 1(2), 06-09.

Yacob, S., M.A.Hassan, Y. Shirai, M.Wakisaka and S.Subahs, 2005. Baseline study of methane emission from open digesting tanks of palm oil mill effluent treatment. Chemosphere, 59, 1575-1581. 